Letrônica, Porto Alegre, v. 7, n. 2, p. 949-965, jul./dez., 2014

\title{
O MOTIVO DA VIAGEM NA LÍRICA DE JORGE DE LIMA
}

THE REASON FOR THE TRIP IN THE LYRIC BY JORGE DE LIMA

\author{
Luciano Dias Cavalcanti*
}

\begin{abstract}
Resumo: Neste texto, pretendemos analisar como Jorge de Lima se utiliza do motivo da viagem - em seus sentidos metafóricos e simbólicos, configurados principalmente nas metáforas do mar e da ilha - na construção de sua poética. Nessa perspectiva, a poesia limiana priorizará o ato da criação concordando com o significado constitutivo da imagem da viagem na modernidade, que se dá, sobretudo, em sua amplitude.

Palavras-chave: Jorge de Lima; Viagem; Ilha; Utopia; Poesia.
\end{abstract}

\begin{abstract}
In this text, we intend to analyze as Jorge de Lima if it uses of reason of the voyage and their metaphorical-symbolic senses like the sea and the island in the construction of its poetical. In this perspective, Lima's poetry will prioritize the act of the creation agreeing to the meaning constituent of the image of the voyage in modernity, that if of, mainly, in its amplitude.
\end{abstract}

Keywords: Jorge de Lima; Voyage; Island; Utopical; Poetry.

O tema da viagem encerra um caráter universal na literatura. Recebemos sua influência e absorvemos algumas de suas características desde o período da formação da Literatura Brasileira. De acordo com Maria Alzira Seixo, o mito da viagem iniciou-se com os Argonautas, para, posteriormente, se enraizar com os poemas homéricos. Mais tarde, na literatura medieval e renascentista (como Auto da Alma e o Pilgrim's Progress), crescerá na viagem o aspecto escatológico. Nesse sentido, a viagem representará o trânsito provisório do homem no mundo, assim como a entrada do ser na duração absoluta da interinidade.

Ritos iniciáticos, espaços, espaços liminares e progressivos, tempos de espessura diferenciada, ritmos diversos de escalas, paragens, desvios, movimentos que sempre de forma humana ou animal, com a utilização em sinédoque do meio de transporte, e em metonímia do território atravessado, se configura e se produzem em escrita. (SEIXO, 1998, p. 12-13).

\footnotetext{
* Doutor em Teoria e História Literária IEL/UNICAMP. Professor do Mestrado em Letras da Universidade do Vale do Rio Verde. Email: bavarov@terra.com.br.
} 
O movimento é a essência da viagem. É o primeiro impulso que leva o viajante a iniciar sua viagem. Portanto, para a viagem avançar em seu deslocamento, o movimento é imprescindível, seja o desejado, seja o imaginado.

A viagem antiga se diferencia da moderna, esta inacabada e inconclusa. A partir do Romantismo, ampliam-se seus limites do real e a viagem passa a se destacar por seu caráter onírico somado ao desejo de fuga e evasão do sujeito. Dessa forma, os relatos modernistas vão se fixar principalmente na distinção do observador, que nos dá, em seu sentido último, sua visão (muitas vezes deformada por seu olhar expressionista) ao invés da descrição.

A poética da viagem apresenta vários desdobramentos. Maria Alzira Seixo os agrupa em três zonas, sendo que as duas primeiras delas muitas vezes se relacionam entre si, estabelecendo um intercâmbio entre o relato histórico e o relato literário e/ou vice-versa. A primeira diz respeito à viagem imaginária e "recobre mitos e textos lendários e alegóricos da Antiguidade e da Idade Média, assim como as utopias, e ainda todos os relatos de viagem da literatura mais recente sem referência do acontecimento circunstancial" (SEIXO, 1998, p. 17); a segunda refere-se à literatura de viagens, que se constitui "por textos diretamente provindos pelas viagens de relações comerciais e de descobrimentos, de exploração e de indagação científica, assim como pelas viagens de escritores que decidem exprimir por escrito as suas impressões referentes a percursos concretamente efetuados"; (SEIXO, 1998, p. 17) a terceira, enfim, diz respeito à viagem na literatura, que é "utilizada como ingrediente literário, em termos de motivo, de imagem, de intertexto, de organizações fabulativas, etc. e que está presente ao longo de toda a história da literatura, com particular acuidade para os séculos posteriores ao Romantismo". (SEIXO, 1998, p. 17).

Dentro dessa perspectiva, um aspecto marcante da viagem diz respeito ao fato de que o tempo e o espaço ocupam caracteristicamente direções opostas, na medida em que, no percurso da viagem, o que se ganha em espaço, se perde em tempo. Outro ponto importante na definição da viagem é o do deslocamento, no sentido de que um lugar é substituído por outro durante o percurso do viajante - (o que pode efetivamente não ocorrer, pois existem vários exemplos de narrativas de viagem clássicas, dos livros de viajantes do Romantismo ou dos diários de viagem ou impressões de viagem de 
escritores ou de personalidades contemporâneas que eliminam o movimento da travessia). (SEIXO, 1998, p. 22).

Mais um elemento de destaque na literatura de viagem é o seu caráter interior, uma espécie de busca de sentido existencial.

E sintomático é que um dos romances decisivos do século, La recherche $d u$ temps perdu, faça da viagem interior e temporal o seu eixo de construção, sem desprezar a viagem física (que pelo contrário se articula em filamentos sabiamente dispersos numa ocupação decisiva do espaço, que é afinal a dimensão primeira dessa temporalidade experienciada e procurada na consciência do ser e na lucidez da escrita). Em qualquer destes romances a viagem configura uma busca do sentido, que passa pela análise do percurso do sujeito no mundo, dos materiais de que vai munido para esse percurso (modalidades do viático), entre os quais se situa a dimensão do outro (que em Conrad é mesmo estranho e estrangeiro), simultaneamente alimento e elemento metamorfoseador, porque entidade individual e atuante, intersubjetividade assumida numa relação de afeto, normalmente a relação amorosa. (SEIXO, 1998, p. 33).

A diversidade semântica que recobre a problemática da viagem na literatura é inegável, mas talvez o mais significativo sentido que a viagem no tempo moderno adquire é o de romper com o espaço e o tempo convencionais. A poesia moderna empreende uma reelaboração desses elementos, no sentido de redimensioná-los, a partir da personalidade individual do poeta, pois a viagem "não significa apenas conquista cumulativa de novos espaços mas, sobretudo, a criação de um espaço em que seja possível reduzir a multiplicidade individual da linguagem da poesia aos parâmetros homogêneos da linguagem do poema. Viagem: linguagem." (BARBOSA, 1986, p. 32). Desse modo, acrescenta o crítico,

\begin{abstract}
assim como a historicidade do poema moderno encontra a ilusão da intemporalidade um correlato preciso para o paradoxo essencial da modernidade, assim é na ilusão da ubiquidade de que a busca pelo poema se converte na ambição maior da destruição de todos os poemas pela instauração do poema único - convergência de todos os tempos e espaços. Até mesmo a prática do fragmento como roteiro para uma poética, como está, por exemplo, em Ungaretti, não faz senão acentuar este pendor do poema moderno: o fragmento é pensado como fragmento no horizonte de um único poema aquele que é possível ler, somente é possível ler, pela procura incessante de uma linguagem perdida. A ilusão da ubiquidade encontra a sua justificação na hipertrofia do espaço poético: aquele em que todas as linguagens não são senão uma só: o poema. (BARBOSA, 1986, p. 32).
\end{abstract}

Na literatura de viagem, o mar é um elemento de extrema importância. Normalmente é por meio dele que a viagem se efetua em seus múltiplos aspectos: é por onde se realiza a trajetória do viajante; e é ele que proporciona aventuras perigosas ou 
até mesmo encontros inusitados com o fabuloso e com as descobertas. 0 mar apresenta alguns traços simbólicos significativos e se caracteriza, por exemplo, pelo seu caráter mutável, pela indefinição na forma, representa a grandiosidade e principalmente se mostra pelo seu caráter de lugar onde se gera a vida. De acordo com Torrano, ao lado da mutabilidade, do grandioso e do informe, o mar representa também "um tipo de sabedoria de inesgotáveis recursos, que prevê o imprevisível, que enxerga o recôndito e o inescrutável; - em suma: uma consciência, que como o Mar, domina, em todas as suas dimensões, a amplidão temporal e espacial." (TORRANO, 1995, p. 62).

Na poética de Jorge de Lima, o mar é um elemento constante, está presente de maneira explícita ou desdobrado em suas várias significações ou elementos. Em sua poesia encontramos: sereias, cavalos-marinhos, estrelas-do-mar, corais, medusas, algas marinhas, delfins, peixes, ilhas, embarcações, marés, conchas, etc.

0 poeta se identifica com o mar de maneira diversa. No "Poema do cristão" ( $A$ Túnica Inconsútil), o poeta se associa a um de seus elementos, a estrela do mar, de modo vivificador.

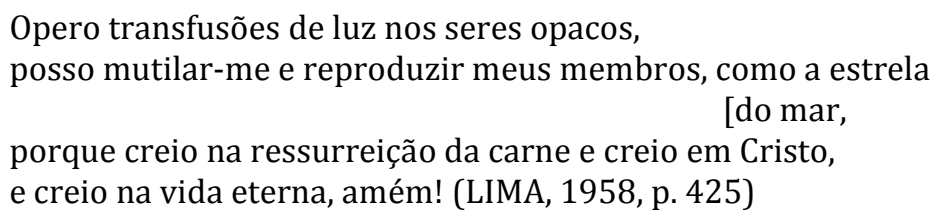

No poema "O poeta que dorme dentro de vós" (A Túnica Inconsútil), sua relação com o mar é extremamente tranquila e amigável.

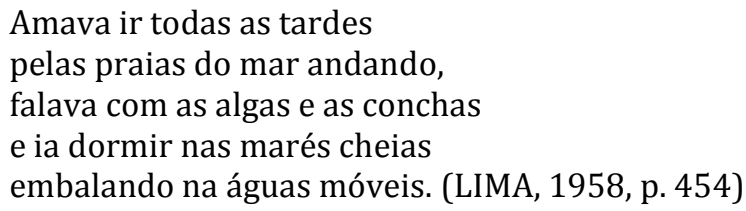

Em “Decassílabo de Maria Helena” (Poesias esquecidas), a ligação do poeta ao mar está estreitamente relacionada ao princípio e ao fim.

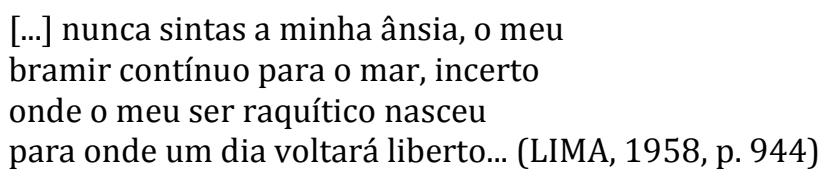

0 mar, no entanto, nem sempre será representado pelo poeta de maneira amigável. Em vários momentos, o ambiente marinho adquire aspectos negativos e se 
torna sombrio, angustiante, tempestuoso e perigoso, confluindo às angústias íntimas do poeta. Os poemas seguintes expressam bem esta perspectiva negativa que o mar apresenta na poética limiana.

\author{
Numa noite longínqua eu acordei \\ com o tremendo rumor da ventania. \\ Que é isso, meu Deus? Olhai o céu, \\ e o vento forte me ensopou de chuva. \\ Vinha com o vento um bruaá de vozes. \\ Donde vinha essas vozes eu não sei. \\ 0 meu navio se perdeu e entrei \\ na mais negra confusão do mundo. \\ A tempestade Senhor! A tempestade \\ com a vossa força arrebatava o mundo.
}

("O poeta perdido na tempestade" In: Tempo e Eternidade. LIMA, 1958, p. 389.)

Suores salgados e amargos de mergulhadores escravos se diluíram no mar.

Suores salgados e amargos de remadores de galeras desceram para o mar.

Sangues salgados e amargos de grandes batalhas navais desceram para o mar.

Lágrimas de sangue dos que ficaram abandonados nos cais correram para o mar.

Sangue derramado nas guerras que a terra embebeu Correu para o mar. (...)

(“Onde está o Mar”. In: A túnica Inconsútil. LIMA, 1958, p. 426)

Mares escuros noturnos

silenciosos mares,

meu navio lá vem

com sua vela branca,

com seus mastros longos

longos mastros que tocam

nas constelações,

para colher as noites

e pescar o silêncio das águas mornas.

(“Noturnos" - In: Poemas Dispersos. LIMA, 1958, p. 948)

Sobre o mar cor de tisna vou

no meu barco pra onde não sei.

A senhora ventania toca

toca matraca pelo ar grosso

Pelo ar grosso me leva

me leva, eu irei.

Irei pelos oceanos noturnos

Onde nunca haja terra

Onde nunca haja rei

Os caminhos do mar não sei

Mas há de haver noites mais moles

Muito mais moles além 
Noites quentes, noites quentes sem lei.

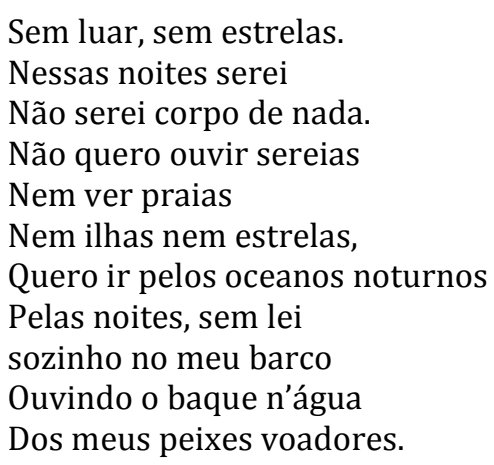

(“Viagem, viagem, viagem” - In: Poemas Dispersos. LIMA, 1958, p. 983)

Dessa forma, as metáforas náuticas constituem um topos frequente na poesia limiana e, como é característico das epopeias, está também presente em Invenção de Orfeu, onde recebe um caráter especial. De acordo com Luiz Busatto, no poema de Jorge de Lima, estes elementos da epopeia se apresentam de forma diferenciada ao negar o referencial histórico de uma "navegação de fuga" (Eneida) ou de "descoberta" (Os Lusíadas), pois Invenção de Orfeu

é uma "viagem escritural". O poeta torna-se marinheiro, e o barco, seu espírito ou sua obra. A viagem marítima é perigosa, especialmente quando dirigida por um "nauta inexperiente" ou em "frágil batel". Por este lado, sem maior digressão, a metáfora náutica em I.O. a aproxima mais da metáfora náutica da Divina Comédia e a afasta mais da metáfora náutica da Eneida e de Os Lusíadas. (...) Esta "acqua" se distancia dos "mares nunca de antes navegados" camoniano, remetendo para um tipo de navegação bem diferente. (BUSATTO, 1978, p. 74).

Esse tratamento singular dado à metáfora náutica é comprovado já no início de Invenção de Orfeu, no Canto Primeiro.

Mesmo nesse fim de mar qualquer ilha se encontrava mesmo sem mar e sem fim mesmo sem terra e sem mim. Mesmo sem naus e sem rumos, mesmo sem vagas e areias, há sempre um copo de mar para um homem navegar.

há aventuras de partidas porém nunca acontecidas (I, II - LIMA, 1958, p.628)

Empreendemos com a ajuda dos acasos as travessias nunca projetadas, sem roteiros e astrolábios 
e sem carta a El-Rei contando a viagem (I, III - LIMA, 1958, p.629)

Busatto conclui seu argumento afirmando que Invenção de Orfeu se baseia no

modelo tradicional da epopeia negando-lhe uma metaforicidade da navegação e criando outra que salienta a necessidade de reinventar o mar, as naus, veleiros, tudo. A reescrituração destas metáforas, fora de um espaço geográfico e fora de um tempo histórico é que individualiza o poema e estabelece as marcas inconfundíveis de I.O. (BUSATTO, 1978, p. 48-49).

O meio de transporte para se fazer uma viagem que mais aparece na literatura é o barco (de grande importância simbólica como lugar do indivíduo e da comunidade). Juntamente com a água (o mar), ambos estabelecem uma fluidez, apresentando um movimento quase automático e espontâneo, o que sugere um ritmo semelhante no texto literário.

Em Invenção de Orfeu a figura do barco não será única. É representado por uma embarcação bêbada e, metalinguisticamente, pelo próprio poema. No primeiro caso, o poema de Jorge de Lima se relacionará precisamente com o poema de Rimbaud, Le Bateau Ivre, texto que influenciou a sua feitura. Em vários momentos de Invenção de Orfeu vemos referência ao poema do escritor francês: na "ébria embarcação" (I, I), no "batel ébrio" (VII, III), no "poema Ivre" (VII, II) e na alusão direta ao poema de Rimbaud (VII, estrofes 364-365), etc. Para Busatto, predominam nas metáforas relacionadas ao Barco Bêbado de Rimbaud a ideia da viagem sem destino conhecido/certo, o que expressa claramente a "inversão do metaforismo básico do gênero" épico. Orientado para uma "viagem escritural" sem categorias fixas, Invenção de Orfeu evidencia seu caráter metalinguístico. (BUSATTO, 1978, p. 52-53).

A "ilha" é outro elemento relacionado ao motivo da viagem que estará sempre presente na poética limiana. 0 vocábulo "ilha" pode ser lido primeiramente no sentido denotativo, de acidente geográfico, em sua referência histórica à Ilha de Santa Cruz; como imagem de Portugal, ilha dentro da Europa ou do próprio Brasil, ilha dentro da América Latina, "linguística, racial e social" (PICCHIO, 1988, p.90), passando pelas conotações de ilhas fabulosas na Antiguidade e no período medieval e pelas idealizações utópicas dos filósofos renascentistas até chegar às conotações simbólicas do paraíso, lugar edênico, aproximando-se gradativamente da ideia de "lugar de poesia". (TELES, 1988, p. 135). A “ilha” recebe várias características ao longo de todo o poema e se 
estrutura num terreno marcadamente literário, relacionando-se, mas também transcendendo, o significado de várias outras ilhas, como as de Dante, de John Milton, de Camões, da Bíblia e também a de Thomas Morus.

De acordo com Gilberto Mendonça Teles, é em Tempo e Eternidade - livro escrito em parceria com Murilo Mendes -, no poema que abre o livro ("Distribuição da poesia"), que aparece pela primeira vez a palavra ilha, e é também neste momento que surgem os sinais da nova concepção poética de Jorge de Lima. A ilha passa a ser vista como o paraíso perdido, próximo de Deus e, portanto, próximo das origens, crescendo na obra do poeta até tornar-se tema central em Invenção de Orfeu.

Mel silvestre tirei das plantas, sal tirei das águas, luz tirei do céu. Escutais, meus irmãos: poesia tirei de tudo para oferecer ao Senhor.

A vida está malograda, creio nas mágicas de Deus. Os galos não cantam, a manhã não raiou. Vi os navios irem e voltarem. Vi os infelizes irem e voltarem. Vi os homens obesos dentro do fogo. Vi ziguezagues na escuridão. Capitão-mor, onde é o Congo? Onde é a Ilha de São Brandão? Capitão-mor que noite escura! Uivam molossos na escuridão. Ó indesejáveis, qual o país, qual o país que desejas? Mel silvestre tirei das plantas, sal tirei das águas, luz tirei do céu. Só tenho poesia para vos dar. Abancai-vos, meus irmãos. (LIMA, 1958, p. 383)

É sintomático, neste poema, o apelo que o poeta faz a Deus pelos oprimidos, como deixa evidente a referência aos escravos negros e ao homem em geral, que se encontram errantes e perdidos num mundo conturbado. É por isso que ele pergunta “Onde é a Ilha de São Brandão?” (LIMA, 1958, p. 383), pois quer encontrar um lugar mítico e paradisíaco diferenciado do mundo em que se encontra. 0 poeta utiliza-se de uma linguagem mítica numa fusão do signo com o objeto como se a palavra fosse o próprio ser, bem característica de Invenção de Orfeu, numa tentativa de reordenar o mundo por meio da palavra poética. Assim, os versos seguintes "A vida está malograda,/creio nas mágicas de Deus./Os galos não cantam,/a manhã não raiou." (LIMA, 1958, p. 383) afirmam a força do verbo, pois sem ele (se os galos não cantarem) o amanhã não nascerá.

O período que compreende a época da publicação de Tempo e Eternidade (1935), momento pelo qual o poeta passa por diversas crises, até a publicação de Invenção de Orfeu (1952) é significativo para a 
biografia de Jorge de Lima. Já percebemos nos seus poemas a expressão do sentimento de desolação e angústia do poeta e seu desejo de superação revelado pelos significados simbólicos da ilha e das metáforas marinhas:

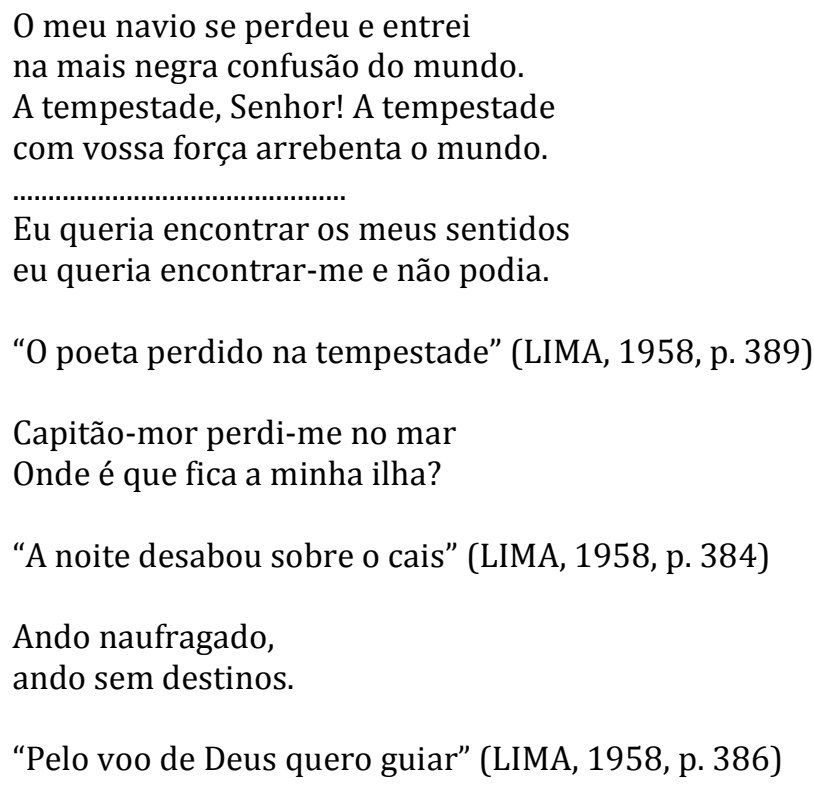

O tema da ilha aparece como título em um poema de $A$ Túnica inconsútil: "Convite para a Ilha" (LIMA, 1958, p. 478). Neste poema vemos a configuração da ilha limiana estreitamente relacionada ao mito do paraíso terrestre, expressão de seu desejo de evasão do mundo real, uma espécie de refúgio numa ilha utópica. Essa ilha é configurada por um ambiente imaginativo, como se nota pela união de elementos contrastantes e estranhos uns aos outros, como demonstram os seres pertencentes a reinos distintos que estão unidos ou metamorfoseados: "peixe cantor", "boto voador" (LIMA, 1958, p.478); também pelo contraste de cores em composições: "baleias azuis" e "ouriço vermelho" (LIMA, 1958, p.478), ou pelo próprio ambiente claramente paradisíaco no poema: "ilha mais bonita não há", "água morna", "rios de leite”, "terras bulindo" (LIMA, 1958, p.478), etc. Desse modo, é perfeitamente visível a configuração do topos do paraíso; no entanto, este topos está configurado de um modo novo, retrabalhado e rearranjado por meio de uma escritura onírica em que não há a preocupação em configurar este mundo de maneira realista ou mimética. Há sim uma intenção de romper com esta forma de representação.

Não digo em que signo se encontra esta ilha mas ilha mais bela não há no alto mar.

0 peixe cantor existe por lá.

Ao norte dá tudo: baleias azuis, 
o ouriço vermelho, o bôto voador.

A leste da ilha há o Geyser gigante

deitando água morna. Quem quer se banhar?

Há plantas carnívoras sem gula que amam.

Ao sul o que há? _ há rios de leite,

há terras bulindo, mulheres nascendo,

raízes subindo, lagunas tremendo,

coqueiros gemendo, areias se entreabrindo.(LIMA, 1958, p.478)

Em Anunciação e Encontro de Mira-Celi, o poema "23", relaciona a figura de MiraCeli ao mar como símbolo da fecundidade e da origem da vida em seu sentido primordial (anterior ao nascimento), em um claro desejo de encontro com a origem e/ou a eternidade.

\footnotetext{
Uma das minhas solidões repousa no lácteo mar de seu ventre; mas os olhos dos pastores e dos nautas sempre se alimentam dela.
}

Na verdade é apenas uma constelação cristã formada nos primeiros dias, com a aparência de cisne, de chama ou de duna em que se ostenta um de meus horizontes.

Ela aspira a vida eterna, meu Deus! (LIMA, 1958, p.523)

Este Livro, singular em toda literatura brasileira, além de conter toda uma simbologia náutica e se caracterizar por seu hermetismo, nos revela muito do que virá adiante na poética de Jorge de Lima. É mesmo uma preparação anunciada para a elaboração de Invenção de Orfeu, que se torna evidente nos versos seguintes: "Os grandes poemas ainda permanecem inéditos" (poema "4" In: LIMA, 1958, p.523); “Os grandes poemas começam com a nossa visão desdobrada" (no poema "56" In: LIMA, 1958, p.522). Chama a atenção também seu caráter circular, no sentido de que o primeiro e o último poema começam da mesma maneira, como se fossem continuidade um do outro: "O inesperado ser começou a desenrolar as suas faixas em que/estava a história da criação passada e futura.". Esse aspecto demonstra o desejo, expresso nos dois poemas (Anunciação e encontro de Mira-Celi e Invenção de Orfeu), do rompimento temporal e do encontro do poeta com a eternidade.

No Livro de Sonetos é grande a quantidade de poemas em que estão presentes as metáforas náuticas. A título de exemplo citamos apenas um, em que se revela a imaginação, a memória, a ilha, o tempo dos primórdios e a associação da criação poética à criação divina. 
dois nevoeiros em oito entrelaçados, galo e penumbra, draga sempre em púbis penetrada de proas dominantes.

E a calmaria toda havia há instantes em círculo de sal e cios porfiados. Desde a baba dos cabos bojadores. Sobre a ilha em vermelhos tão agudos.

A brisa em nascimento cai em chuva, abrem-se os ventres da água primitiva, logo embebidos, logo despejados.

Cordilheiras parindo coisas como.

E outros montes mais virgens dividindo-se.

E Deus babando sobre o mundo do início. (LIMA, 1958, p.591)

A presença da Ilha também é notada no título de um livro, As Ilhas, que o poeta publicou nas Edições Hipocampo de Niterói, em 1952. É o mesmo ano da publicação de Invenção de Orfeu, e constitui o poema VI do canto IV desse livro.

Ao ser questionado sobre o local onde decorre Invenção de Orfeu, Jorge de Lima responde:

\begin{abstract}
Numa Ilha ideal-real, porque não existe geograficamente (toda a geografia do poema é inespacial), mas real, porque ao contrário da de Thomas Morus, onde os seres são perfeitos, nesta há miséria, sofrimentos, guerras. É uma ilha que tem um subsolo e um supersolo. O poema abrange o cotidiano, o natural, o prenatural, o sobrenatural e o angélico. (LIMA, 1958, p. 93).
\end{abstract}

Desse modo, não é impróprio considerar que a Ilha possa significar uma imagem fundamental, que conduz a estruturação do poema em relação à busca empreendida pelo poeta, de encontrar a eternidade perdida com a queda do homem no paraíso. São exemplares as epígrafes bíblicas dadas ao poema: "E, quando a casa se edificava, faziamna de pedras lavradas e perfeitas; e não se ouviu martelo, nem machada, nem instrumento algum de ferro, enquanto ela se edificava." (III Reis, 7 In: LIMA, 1958, p.625). Simboliza a imensidão espacial que a casa ocupa, como também o caráter maravilhoso de sua construção, o que nos remete a um tempo mítico em que a criação acontece de forma espontânea. Assim também aponta a epígrafe retirada de Isaías 42,10: "Eu anuncio coisas novas, ilhas cantai um canto novo" (LIMA, 1958, p.625). Utilizando-se das palavras do Profeta para vislumbrar uma vida feliz, o poeta convida as ilhas a cantarem um canto novo, evidenciando, desde já, antes mesmo de iniciar o seu poema, sua associação ao profeta. De maneira geral, no sentido religioso, a expressão "ilha" sempre nos remete a lugares distantes que devem ser "evangelizados" ou 
precisam conhecer a palavra de Deus, podendo significar, também, a imagem do homem mesmo, num sentido metonímico (o lugar pelo habitante). Em muitos momentos, esta imagem bíblica será referida, em Invenção de Orfeu, principalmente no que diz respeito ao desejo do poeta em encontrar a harmonia perdida e na busca da confraternização entre os homens. Ao lado da citação bíblica, aparece o texto de Apollinaire: "IL Y A". Este texto descreve basicamente a comunhão entre pessoas que vivem felizes e em harmonia com a natureza; seu título inegavelmente revela, a partir de sua sonoridade, a semelhança com a palavra Ilha.

A ilha no poema de Jorge de Lima será múltipla e receberá, dentro da perspectiva adotada acima, uma variada significação: não tem uma localização determinada e também pode ser considerada total "de aquém e além mar" [I, I] (LIMA, 1958, p.627); encontrar-se no homem "A ilha ninguém a achou/porque todos a sabíamos." [I, II]; (LIMA, 1958, p.628) é seu sonho de infância "Desse leite profundo emergido do sonho/coagulou-se essa ilha essa nuvem e esse rio" [I, XVI] (LIMA, 1958, p.638); é criada pela escrita poética e é utópica "Quem vos mandou inventar índios... Morus,/ilhas escritas, Morus, ó Morus?" [I, XXXI] (LIMA, 1958, p.656); encarna a figura do poeta e seu espaço “ó veneza dos dogmas e poetas!” [I, XXXVIII] (LIMA, 1958, p.673); é originária da poesia - Inês "As fontes dulçurosas desta ilha/promanam da rainha viva-morta" [II, XIX] (LIMA, 1958, p.704); é espaço de vivência pessoal "seu passado nos olhos ainda brilha." [IV, XII] (LIMA, 1958, p.744); sua temporalidade é circular "Que é uma ilha senão um círculo" [IV, XXIII] (LIMA, 1958, p.752); representa o homem em conflito "os infernos de ilhas solitárias/abandonadas aos inquietos ventos" [IV, XXVIII] (LIMA, 1958, p.755); representa a própria viagem do poeta "Viagem e ilha/ a mesma coisa" [VII, II] (LIMA, 1958, p.775); é o espaço do julgamento final "No centro um tribunal. Eu me recordo/que havia em meio a ilha um tribunal" [VII, V] (LIMA, 1958, p.778); é o poeta em comunhão "Maduro pelos dias, vi-me em ilha, porquanto/como conhecer as coisas senão sendo-as" [VII, XIV]; (LIMA, 1958, p.808)é particular e universal "que não sou eu por essas ilhas vossas,/nem ilha singular, porém plural,/porém comuna de ilhas, arquipélago, federação de Deus, louvando Deus." [VIII] (LIMA, 1958, p.625); etc. Desse modo, é bom enfatizar que nas múltiplas significações da ilha se destaca o desejo do poeta de encontrar a união entre os homens para que possa haver uma futura comunhão universal. Seu desejo é, 
pois, reconquistar o paraíso perdido através do natural, do sobrenatural, de Deus e na soma de todos os tempos (passado, presente e futuro).

Invenção de Orfeu inicia-se com o canto denominado "Fundação da Ilha", e o termo "fundação" é bem sugestivo, já que denota o estabelecimento dos alicerces para a edificação de seu poema. Portanto, o que o poeta pretende é estabelecer a base de seu poema (o que sustenta e possibilita qualquer edificação).

É exemplar a sua primeira estância, momento em que o poeta estabelece a proposição do poema e nos apresenta seu herói, seu roteiro e seus objetivos, e nos diz qual é a ilha buscada por ele, uma ilha utópica. Etimologicamente, a palavra utopia recebe o significado de não-lugar (está fora do tempo e do espaço). A ilha buscada pelo poeta é também caracterizada de forma semelhante à utopia, pois ela é "de aquém e de além-mar" (LIMA, 1958, p.627), portanto não está em um lugar determinado, não sendo possível localizá-la, como revelam os termos assinalados: aquém (prep. e adv. do lado de cá de; inferiormente; abaixo; menos [antôn.: além]) e além (adv. acolá; mais adiante; mais longe [antôn.: aquém] - s.m. lugar distante; outras terras; lugar fronteiro a outro elemento de composição de palavras com o sentido de "além de": além-mar; alémtúmulo). (Dicionário Aurélio, 1998, s/p) Desse modo, a ilha limiana pode ser entendida como utópica, pois situa-se em um lugar que não existe, reportando-nos para uma realidade irreal. É interessante notar que, além da ilha não ter uma localização específica, ela é caracterizada por uma contradição ou pelo menos por um paradoxo, que é revelado por sua (não)determinação por meio de palavras antônimas, trazendo-lhe ainda mais obscuridade. A ilha também pode ser considerada total, mesmo não recebendo nenhuma localização; afinal, pode-se entender que ela ocupa um espaço que vai de aquém até além mar. Significado este que reforça ainda mais seu caráter utópico. O seu significado final a associa à busca e ao maior símbolo da fraternidade, o amor, como sugere a primeira estrofe, paródia do épico de Camões.

Esta localização indefinida da ilha nos remete também a um tempo original, associado à busca de um espaço sagrado também sem limites e, portanto, primordial. No tempo primordial dá-se a união entre passado, presente e futuro, caracterizando a celebração de um tempo mítico que contém a vida humana em sua totalidade. Nesse sentido, o passado se torna arquetípico, isto é, um passado que é potencialmente um futuro aparelhado para se encontrar com o presente. Desse modo, o herói dessa 
pretendida epopeia buscará conquistar o espaço primordial através da memória. Este aspecto da simultaneidade, presente na poética moderna, nos remete ao desejo do poeta moderno de querer reduzir distâncias através da possibilidade da aproximação espacialtemporal feita, muitas vezes, por suas metáforas, que associam termos dissonantes, e também pelo seu desejo de evasão do mundo em que vive. Esta comunhão entre os três tempos representa uma simultaneidade almejada pela poesia no intuito de eliminar os limites temporais, como vemos de forma explícita na viagem empreendida pelo herói limiano.

\author{
Um Barão assinalado \\ sem brasão, sem gume e fama \\ cumpre apenas o seu fado: \\ amar, louvar sua dama, \\ dia e noite navegar, \\ que é de aquém e de além-mar \\ a ilha que busca e o amor que ama. \\ Nobre apenas de memórias, \\ vai lembrando de seus dias, \\ dias que são as histórias, \\ histórias que são porfias \\ de passados e futuros, \\ naufrágios e outros apuros, \\ descobertas e alegrias. \\ Alegrias descobertas \\ ou mesmo achadas, lá vão \\ a todas as naus alertas \\ de vária mastreação, \\ mastros que apontam caminhos \\ a países de outros vinhos. \\ Esta é a ébria embarcação. \\ Barão ébrio, mas barão, \\ de manchas condecorado; \\ entre o mar, o céu e o chão \\ fala sem ser escutado \\ a peixes, homens e aves, \\ bocas e bicos, com chaves, \\ e ele sem chaves na mão. (LIMA, 1958, p. 627).
}

Nesse sentido, Invenção de Orfeu apresenta, já no seu início, pelo menos três das temáticas mais importantes e constantes do poema: a do herói (representado pelo próprio poeta que cumpre uma missão - Barão ébrio -, o que lhe dá um caráter cristão por estar sujeito à vontade de Deus); a da viagem (que pode representar tanto a própria 
vida do homem, que metaforicamente "viaja" de seu nascimento até a morte, como também de uma viagem apenas imaginária e metalinguística) e a da ilha (que é a meta do herói e, como acreditamos, pode representar a metáfora central do poema).

Dentre os elementos presentes nesta estância, destaca-se, primeiramente, a figura do Barão (como é caracterizado o herói do poema), que carrega, originalmente, o sentido de nobreza, conduzindo-nos a uma imagem característica do herói marcado por atitudes de coragem e de grandes feitos, remetendo-se diretamente ao herói camoniano d'Os Lusíadas. A relação deste com o herói limiano, no entanto, é em seguida desmistificada a partir de sua caracterização como "ébrio", que imediatamente o associa à tradição poética da modernidade (Rimbaud). Posteriormente, encontramos um elemento que se mostra de grande importância para todo o poema, uma "chave" 1 , pois ela simboliza uma espécie de artefato capaz de restaurar a harmonia perdida pelo homem com a Queda. É a busca deste artefato e/ou da reconquista da perfeição que sustenta a aventura do herói-poeta em sua epopeia. Esta busca mítica fundamental da humanidade e suas referências intertextuais às epopeias clássicas também nos remetem ao poder revelador da palavra poética. Nesse sentido, o paraíso perdido é recuperado através da palavra, da poesia. E, desse modo, outro elemento importante no poema de Jorge de Lima se apresenta nessa estância, Orfeu. Herói de sua epopeia que se confunde com o próprio poeta e seu ofício, ele é a figura que orienta a busca da harmonia perdida. Portanto, a chave buscada está dentro do próprio herói, é a própria poesia ou a palavra poética.

Podemos ver nessas imagens da "ilha-poema" um artifício metalinguístico, utilizado pelo Poeta como teorização da metáfora do "poeta-engenheiro", que se vale da técnica e do onírico para criar o modelo da escritura de seu poema. Toda linha metafórica do poema se questiona por meio de seus signos e símbolos e por sua linguagem e se estabelece na própria escritura do poema. Essa vasta multiplicidade caracterizada pelo movimento contínuo de Invenção de Orfeu revela-se na diversidade

\footnotetext{
${ }^{1}$ Em suas "Memórias", o poeta se refere a uma chave que marcou suas lembranças. Isso pode significar que realmente Jorge de Lima está em busca desse momento, do retorno à infância perdida. Nesse sentido, a viagem empreendida pelo nauta-poeta em Invenção de Orfeu representaria a tentativa de reconquistar esse tempo paradisíaco da infância: "Lembrança da Casa-grande tenho muita que depois tratarei, como por exemplo da sala das chaves, chaves enormes de ferro penduradas a seus ganchos: trinta com os destinos, do paiol, do escritório, da despensa, da capela, capela de Santana onde havia missal no altar-mor e sacristia com gavetões de jacarandá." (LIMA, 1958, p. 99).
} 
das imagens em movimento, que busca encontrar a verdade do início dos tempos (anterior à Queda), realizada na poesia e pela poesia.

As imagens de retorno e de recomeço estão presentes ao longo de Invenção de Orfeu num processo às vezes circular contínuo, às vezes em forma de espiral, onde temas de sua memória se encontram lado a lado. Assim, o poema se faz a partir da união do fragmento, o todo se faz do fragmento e o todo está também no fragmento.

A preocupação com o conteúdo do texto desloca-se para a preocupação com a forma do texto, visão metalinguística que percorre todo o poema, principalmente caracterizado pela técnica da montagem, processo de composição que desmistifica o texto enquanto "intocável", ou com uma tradição que conceberia a obra como "acabada". 0 texto passa a se decompor em outros mais, estabelecendo uma "circularidade" e/ou "espiralidade" que possibilita o diálogo intertextual com outros textos, do mesmo modo que com ele próprio.

A Ilha de Jorge de Lima caracteriza tanto o espaço interior do poeta, sendo, portanto, caracteristicamente subjetiva, como também se volta para o mundo visual e exterior, configurando este mundo através de seus significados, conciliando no poema, assim, o subjetivismo espiritualista e o realismo sensorial das coisas materiais.

A ilha figura em todo o poema como repositório de imagens, acontecimentos e aspiração. Ela resume esperanças e desilusões, convertida em última mensagem. Baudelaire diz que "para se penetrar a alma de um poeta, tem-se de procurar palavras que aparecem mais amiúde em sua obra. A palavra delata qual é a sua obsessão" (apud FRIEDRICH, 1991, p. 45); assim, poderíamos dizer que "Ilha" é, possivelmente, uma palavra-chave capaz de revelar muito sobre a poética limiana.

0 projeto poético de Jorge de Lima parece se revelar por meio da busca de algo inalcançável. A ilha, metáfora constante em sua poética, está estreitamente relacionada à busca do poeta (do homem) por algo não acabado e não realizável: o absoluto, a felicidade plena, o resgate do tempo original após a Queda. Nesse sentido, a navegação empreendida pelo poeta, além de caracterizar-se por seu caráter metalinguístico, também pode ser considerada a mesma viagem de cada ser humano no decorrer de sua própria vida, em busca de suas realizações íntimas e sociais. 


\section{Referências}

BARBOSA, João Alexandre. As ilusões da modernidade. São Paulo: Perspectiva, 1986.

BUSATTO, Luiz. Montagem em Invenção de Orfeu. Rio de Janeiro: Âmbito Cultural, 1978.

DICIONÁRIO AURÉLIO. São Paulo: Ed. Positivo, 1998.

FRIEDRICH, Hugo. Estrutura da lírica moderna: problemas atuais e suas fontes. São Paulo: Duas Cidades, 1991.

LIMA, Jorge de. Obra Completa (Org. Afrânio Coutinho). Rio de Janeiro: Aguilar, 1958.

PICCHIO, Luciana Stengagno. O Poeta e sua dimensão universal. In: RÈBAUD, Jean-Paul (Org.) 90 anos de Jorge de Lima (Anais do Segundo Simpósio de Literatura Alagoano). Maceió: UFAL, 1988.

SEIXO, Maria Alzira. Poéticas da viagem na literatura. Lisboa: Edições Cosmos, 1998.

TELES, Gilberto Mendonça. Jorge de Lima e a geração de 1893. In: RÈBAUD, Jean-Paul (Org.) 90 anos de Jorge de Lima (Anais do Segundo Simpósio de Literatura Alagoano). Maceió: UFAL, 1988.

TORRANO, Jaa. Estudo e tradução: HESíODO. Teogonia - A origem dos deuses. São Paulo: Iluminuras, 1995.

Recebido em maio de 2014.

Aceito em outubro de 2014. 